\title{
Segregation of Mn, Si, Al, and Oxygen During the Friction Stir Welding of DH36 Steel
}

\author{
M. Almoussawi ${ }^{1,2} \cdot$ A. J. Smith ${ }^{1}$ M. Faraji ${ }^{3} \cdot$ S. Cater $^{4}$
}

Received: 3 July 2017/Revised: 25 August 2017/Accepted: 26 September 2017/Published online: 13 November 2017

(c) The Author(s) 2017. This article is an open access publication

\begin{abstract}
This work investigates the role of welding speed in elemental segregation of $\mathrm{Mn}, \mathrm{Si}, \mathrm{Al}$, and oxygen during friction stir welding (FSW) in DH36 steel. The experimental work undertaken showed that when the speed of the FSW process exceeds 500 RPM with a traverse speed of $400 \mathrm{~mm} / \mathrm{min}$, then elemental segregation of $\mathrm{Mn}, \mathrm{Si}, \mathrm{Al}$, and $\mathrm{O}$ occurred. The mechanism of this segregation is not fully understood; additionally, the presence of oxygen within these segregated elements needs investigation. This work examines the elemental segregation within DH36 steel by conducting heat treatment experiments on unwelded samples incrementally in the range of $1200-1500{ }^{\circ} \mathrm{C}$ and at cooling rates similar to that in FSW process. The results of heat treatments were compared with samples welded under two extremes of weld tool speeds, namely W1 low tool speeds (200 RPM with traverse speed of $100 \mathrm{~mm} / \mathrm{min}$ ) and W2 high tool speeds (550 RPM with traverse speed of $400 \mathrm{~mm} / \mathrm{min}$ ). The results from the heat treatment trials showed that segregation commences when the temperature exceeds $1400^{\circ} \mathrm{C}$ and $\mathrm{Mn}, \mathrm{Si}, \mathrm{Al}$, and oxygen segregation progress occurs at $1450{ }^{\circ} \mathrm{C}$ and at a cooling rate associated with acicular ferrite formation. It was also found that high rotational speeds exceeding 500 RPM caused localized melting at the advancing-trailing side of the friction stir-welded samples. The study aims
\end{abstract}

\footnotetext{
M. Almoussawi

b1045691@my.shu.ac.uk; inj.mun@atu.edu.iq

MERI, Sheffield Hallam University, Sheffield S1 1WB, UK

2 Al-Furat Al-Awsat Technical University, Kufa, Iraq

3 School of Mechanical, Aerospace and Automotive Engineering, Coventry University, Coventry, UK

4 TWI Yorkshire, Catcliffe, UK
}

to estimate peak temperature limits at which elemental segregation does not occur and hence prevent their occurrence in practice by applying the findings to the tool's rotational and traverse speed that correspond to the defined temperature.

Keywords Friction stir welding · DH36 steel - Elemental segregation

\section{Introduction}

Since FSW was invented in 1991 by The Welding Institute (TWI), much effort has been put into its commercialization latterly for higher melting point materials such as steel [1]. The High Integrity Low Distortion Assembly (HILDA) project is an example of this effort which is aiming to understand the process of FSW of a DH36 galvanized steel grade including microstructure evolution, modeling, mechanical properties and defect formation during FSW [1]. In earlier work, Toumpis et al. [1] examined the effect of the FSW tool traverse and rotational speeds on the microstructure evolution and mechanical properties of 6-mm-thick DH36 steel. It was found that the microstructure became heterogeneous and mechanical properties declined when high rotational and traverse speeds (exceeding $650 \mathrm{RPM}$ and $500 \mathrm{~mm} / \mathrm{min}$, respectively) were applied. In another paper by the same authors [2] on mathematical modeling of the FSW process using computational fluid dynamics (CFD) technique, they reported that a maximum temperature of $1250{ }^{\circ} \mathrm{C}$ was computed when the rotational and traverse speeds were 500 RPM and $400 \mathrm{~mm} / \mathrm{min}$, respectively. A comparison between FSW and submerged arc welding (SAW) of DH36 showed microstructure and mechanical properties improved as a 
result of applying the FSW technique [3]. Advantages of FSW of DH36 steel were also studied [4] by relating welding parameters to mechanical properties. Defects associated with FSW of DH36 steel were reported by Stevenson et al. [5] and classified into five groups, namely lower embedded, upper embedded, incomplete fusion, connectivity flaw, and root flaw. Most of these flaws were suggested to have resulted from a lack in material flow due to high traverse speeds. Thermal stresses as a result of local heating during FSW of DH36 were also studied [6] and were calculated numerically from a thermomechanical model. They were found to be below the manufactured yield stress of the alloy. The maximum measured temperature was also below the alloy's melting point. It is noticed that previous work on FSW of DH36 steel did not investigate the possibility of elemental segregation as a significant type of defect which could deteriorate the mechanical properties of the welded joints. Also there exists no previous numerical or experimental measurement of the peak temperature during the FSW process that reported localized melting. In the current work, for the first time, the mechanism responsible for elemental segregation in FSW of 6-mm DH36 steel is investigated by applying two FSW tool speeds, $W 1$ (200 RPM, $100 \mathrm{~mm} / \mathrm{min})$ and $W 2$ (550 RPM, $400 \mathrm{~mm} / \mathrm{min}$ ). Alongside FSW, unwelded samples of DH36 steel were heat-treated in a temperature range of $1200-1500{ }^{\circ} \mathrm{C}$ and then subjected to cooling rates similar to that in FSW. This is in an effort to produce very similar microstructure to FSW samples in a controlled environment to be able to determine the temperature and cooling rate which cause elemental segregation. The heat treatments $\left(1200-1500{ }^{\circ} \mathrm{C}\right)$ were conducted with holding times between 1 and $10 \mathrm{~min}$ to understand how the segregation starts and advances. This work aims to determine the limits of FSW tool speed that cause elemental segregation and also to estimate the maximum peak temperature that the welded joint experienced during FSW.

\section{Experimental Procedure}

The as-received chemical composition of the 6-mm-thick DH36 steel is shown in Table 1. The top surface of plate is covered by a galvanized layer of $\mathrm{Zn}$. The plates were friction stir welded at TWI (Yorkshire) using the FSW "PowerStir" machine. A hybrid poly-crystalline boron nitride (PCBN) tool was used with a shoulder of $25 \mathrm{~mm}$ diameter and probe of $5.7 \mathrm{~mm}$ length. Samples were produced using low
(200 RPM, $100 \mathrm{~mm} / \mathrm{min}$ ) and high (550 RPM, $400 \mathrm{~mm} /$ min) speeds which are named as $W 1$ and $W 2$, respectively, from now on. Thermocouples were embedded in positions down the length of the weld in an attempt to establish the peak temperature achieved during welding. It is worth to mention that fixing thermocouples in the tool/workpiece contact region or in the stirred zone can lead to errors in the temperature readings as thermocouples may move before recording the maximum temperature [TWI experiments].

Furnace heat treatments of 24 samples of DH36 $(6 \mathrm{~mm}$ cubic) were carried out between 1200 and 1500 at $50{ }^{\circ} \mathrm{C}$ intervals and then quenched in either hot oil $\left(150^{\circ} \mathrm{C}\right)$ or oil at ambient temperature $\left(22^{\circ} \mathrm{C}\right)$ which produced cooling rates of $\left(30^{\circ} \mathrm{C} / \mathrm{s}\right)$ and $\left(50{ }^{\circ} \mathrm{C} / \mathrm{s}\right)$, respectively. The surface temperature of the samples was checked by the attachment of W-Re thermocouples. Strain rate effect was not included in the heat treatments as the maximum temperature on Gleeble simulator hot compression test is not exceeding $1100{ }^{\circ} \mathrm{C}$ and the current heat treatments are mainly in temperature ranges of $1400-1500{ }^{\circ} \mathrm{C}$. However, it is expected that strain rate will affect mainly the time of phase transformation and elemental precipitation/segregation as proved by previous work [7-12]. Heat-treated samples were sectioned, polished to 1-micron finish, and etched in $2 \%$ nital to reveal the microstructure. Samples were examined using both scanning electron microscopy (SEM) and energy-dispersive x-ray spectroscopy (EDS).

\section{Results and Discussion}

The SEM micrographs of cross sections of the as-received base metal show a matrix of ferrite grains $(7-9 \mu \mathrm{m})$ with bands of pearlite (Fig. 1a) and nanoscale-sized interstitial elements such as $\mathrm{Ti}$ and $\mathrm{Nb}$ (Fig. 1b). Ca that has a strong affinity to form sulfides and oxides was found in the DH36 plate as a compound of calcium aluminates $\left(\mathrm{CaO}-\mathrm{Al}_{2} \mathrm{O}_{3}\right)$ and also calcium-manganese-sulfide ( $\mathrm{MnS}-\mathrm{CaS})$ as shown in Figs. 2 and 3, respectively. The melting point of $(\mathrm{CaO}-$ $\mathrm{Al}_{2} \mathrm{O}_{3}$ ) is in the range of $1450-1850{ }^{\circ} \mathrm{C}$ depending on the amount of $\mathrm{CaO}$ compound with $\mathrm{Al}_{2} \mathrm{O}_{3}$ [13]. Pure $\mathrm{MnS}$ melts at $1600{ }^{\circ} \mathrm{C}$, but it is expected that the melting point is lower when it forms compounds with other elements [14]. Hence, it is expected that some melting of the $\mathrm{CaO}-\mathrm{Al}_{2} \mathrm{O}_{3}$ and also $\mathrm{MnS}-\mathrm{CaS}$ occurs when temperature exceeds $1400{ }^{\circ} \mathrm{C}$.

It is recognized that the samples heat treatments are nonequilibrium. The samples are heated between 1 and $10 \mathrm{~min}$ which is insufficient time for the whole sample to reach the
Table 1 Chemical composition of as-received DH36 steel (wt.\%)

\begin{tabular}{llllllllllllll}
\hline $\mathrm{C}$ & $\mathrm{Si}$ & $\mathrm{Mn}$ & $\mathrm{P}$ & $\mathrm{S}$ & $\mathrm{Al}$ & $\mathrm{N}$ & $\mathrm{Nb}$ & $\mathrm{V}$ & $\mathrm{Ti}$ & $\mathrm{Cu}$ & $\mathrm{Cr}$ & $\mathrm{Ni}$ & $\mathrm{Mo}$ \\
\hline 0.16 & 0.15 & 1.2 & 0.01 & 0.005 & 0.043 & 0.02 & 0.02 & 0.002 & 0.001 & 0.029 & 0.015 & 0.014 & 0.002 \\
\hline
\end{tabular}



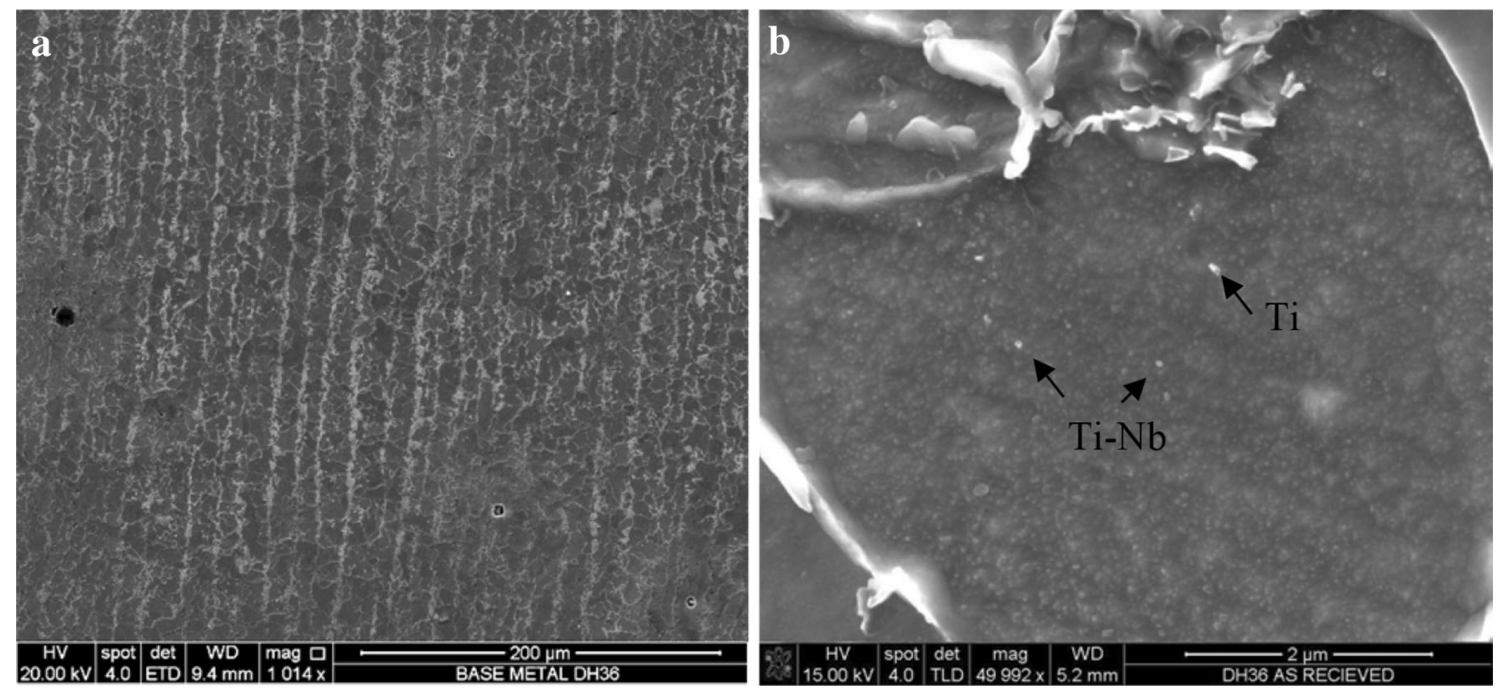

Fig. 1 SEM images of cross sections of as-received DH36. (a) A matrix of ferrite grains with bands of pearlite. (b) Is a high-magnification image showing $\mathrm{Nb}$ - and Ti-rich precipitates
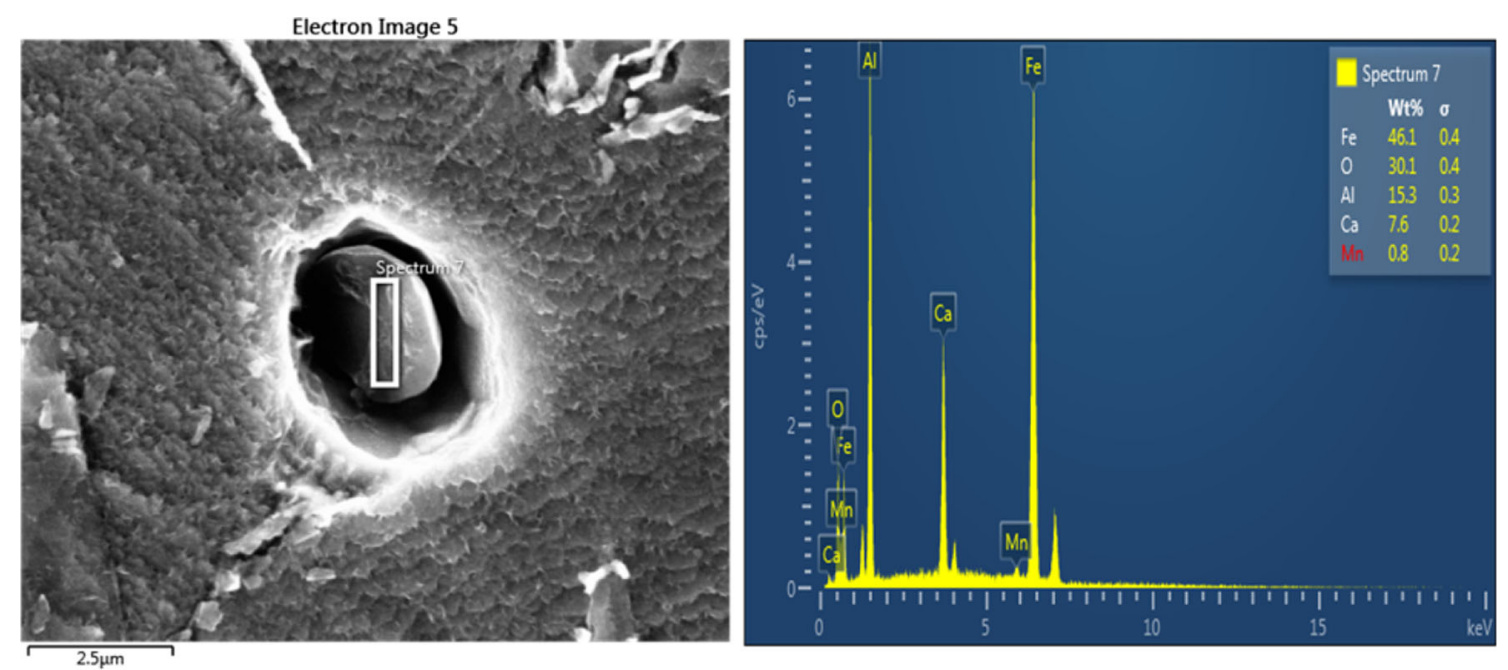

Fig. 2 SEM micrograph of as-received DH36 steel and its corresponding EDS map showing a compound of calcium aluminate $\left(\mathrm{CaO}_{-} \mathrm{Al}_{2} \mathrm{O}_{3}\right)$

same temperature. The heating temperature is designed to simulate the surface temperature that a FSW sample would experience. It is also expected that the high strain rate which exist in the FSW will also reduce the time required for elemental precipitation/segregation as proved by previous work [7-12]. Heat treatments up to a temperature of $1400{ }^{\circ} \mathrm{C}$ followed by ambient and hot oil quenching showed a significant segregation of $\mathrm{MnS}$ compound with $\mathrm{Nb}$ as shown in Fig. 4a and b for quenching in ambient oil. The segregation of MnS and its detrimental effects on hot tensile fracture was studied by Santillana et al. [15]. They found that segregation is occurring at a temperature range up to $1440{ }^{\circ} \mathrm{C}$ which is close to the temperature in the current study. Figure 5 shows the microstructure of a sample heat treatment at $1450{ }^{\circ} \mathrm{C}$ followed by hot oil quenching (at two different magnifications). It shows that a significant segregation has occurred (Fig. 5a) and was associated with acicular ferrite formation (Fig. 5b). Comparing Figs. 4 and 5, it is evident that the segregation of spinel elements of $\mathrm{Mn}, \mathrm{Si}, \mathrm{Al}$, and $\mathrm{O}$ only occurs at temperatures exceeding $1450{ }^{\circ} \mathrm{C}$ with a cooling rate sufficient to cause the formation of an acicular ferrite microstructure. This phenomenon requires more in-depth investigation, and the current work only focuses on the observation of this segregation.

Figure 6 shows the microstructure of $W 1$ and $W 2$, respectively, and both welds appear to have a microstructure of acicular ferrite and bainite; however, segregation of $\mathrm{Mn}, \mathrm{Si}, \mathrm{Al}, \mathrm{O}$ elements appears only in the $W 2$ joint stir zone. Figure 7 shows SEM-EDS of $\mathrm{Mn}, \mathrm{Si}, \mathrm{Al}, \mathrm{O}, \mathrm{Zn}$ 

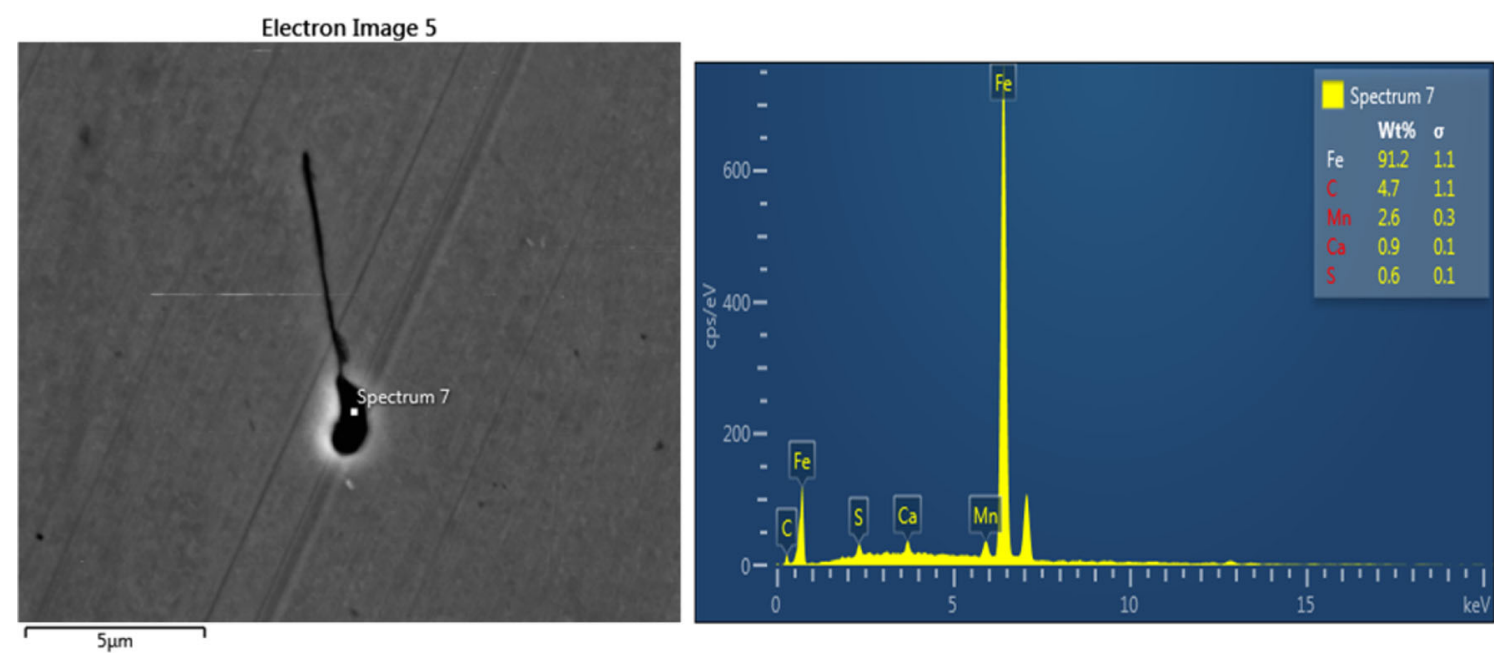

Fig. 3 SEM micrograph of as-received DH36 steel and its corresponding EDS spectrum showing manganese-calcium-sulfate (MnS-CaS) inclusions
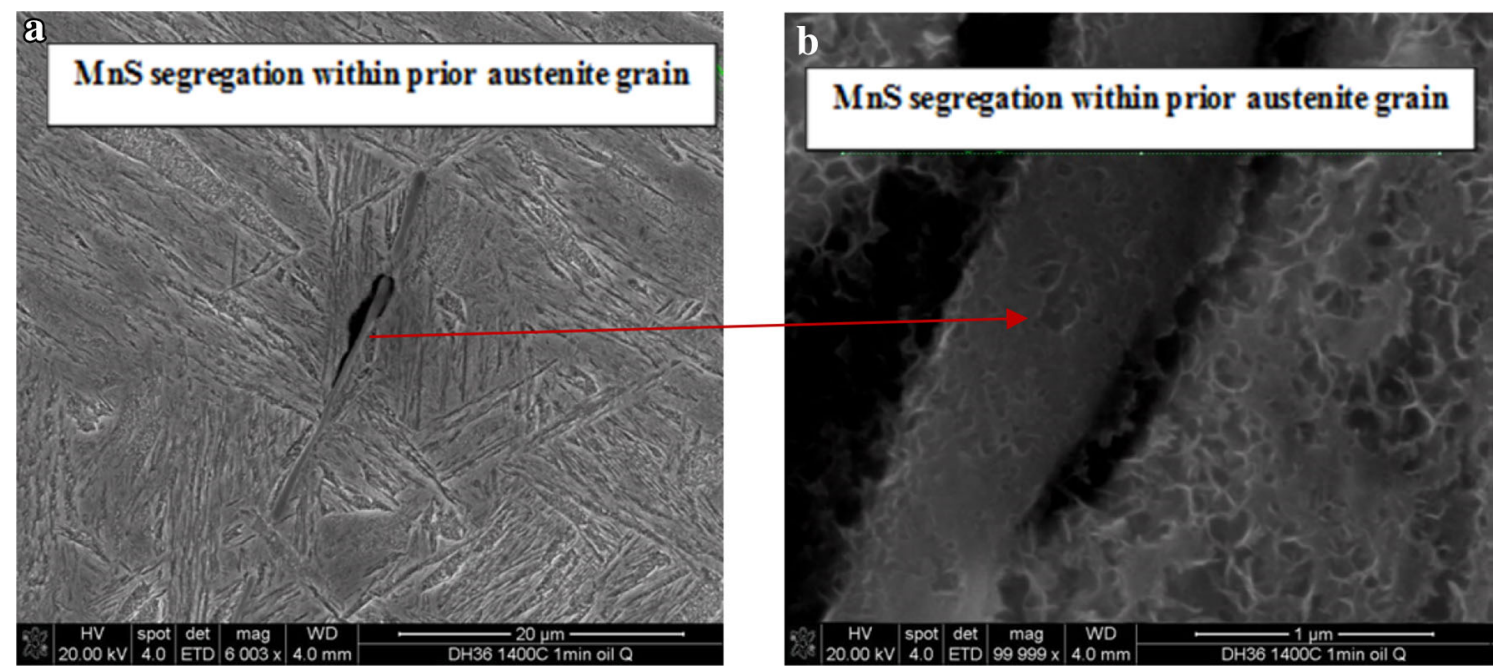

Fig. 4 SEM micrographs of DH36 steel showing segregation of MnS-Nb within prior austenite grain at $1400{ }^{\circ} \mathrm{C}, 1$-min oil quenching, for (a) low magnification, for (b) higher magnification

segregation in $W 2$. The $\mathrm{Zn}$ present in the second-phase particle shown in Fig. 7 will have originated from the galvanized surface of the DH36 steel. Smith et al. [16] suggested from CFD modeling that the maximum peak temperature in FSW of 304 stainless steel is localized at the tool/workpiece contact surface on the advancing-trailing side and it can reach close to the melting point when the tool speed exceeds 400 RPM. The melting and boiling temperatures of $\mathrm{Zn}$ are $693 \mathrm{~K}\left(420{ }^{\circ} \mathrm{C}\right)$ and $1180 \mathrm{~K}$ $\left(907{ }^{\circ} \mathrm{C}\right)$, respectively, welding peaks temperatures especially at the tool/workpiece contact region are expected to be higher than the boiling temperature of $\mathrm{Zn}$, and thus, the possibility of $\mathrm{Zn}$ present in the stirred zone (SZ) should be low. Beak et al. [17] explained the existence of $\mathrm{Zn}$ in the stirred zone as a result of a tool effect, whereby $\mathrm{Zn}$ will melt and evaporate during FSW, but because there is no way for it to escape outside the tool/workpiece contact region, it will explode into the SZ. In this paper, an interpretation to coalesce $\mathrm{Zn}$ with other elemental segregation in W2 FSW sample can be as follows: (a) The centrifugal forces from FSW tool are pushing the steel including the $\mathrm{Zn}$-coated layer at tool/workpiece contact surface to the advancing-trailing side during the FSW. (b) Heat generated during the FSW results in a peak temperature at the advancing-trailing side which exceeds $1400{ }^{\circ} \mathrm{C}$. (c) And at a cooling rate in the range of $10-30{ }^{\circ} \mathrm{C} / \mathrm{s}$, segregation occurs as shown previously by heat treatments for the peak temperature and cooling rate required for segregation. (d) The segregated elements are moved from the top surface of advancing-trailing side and 

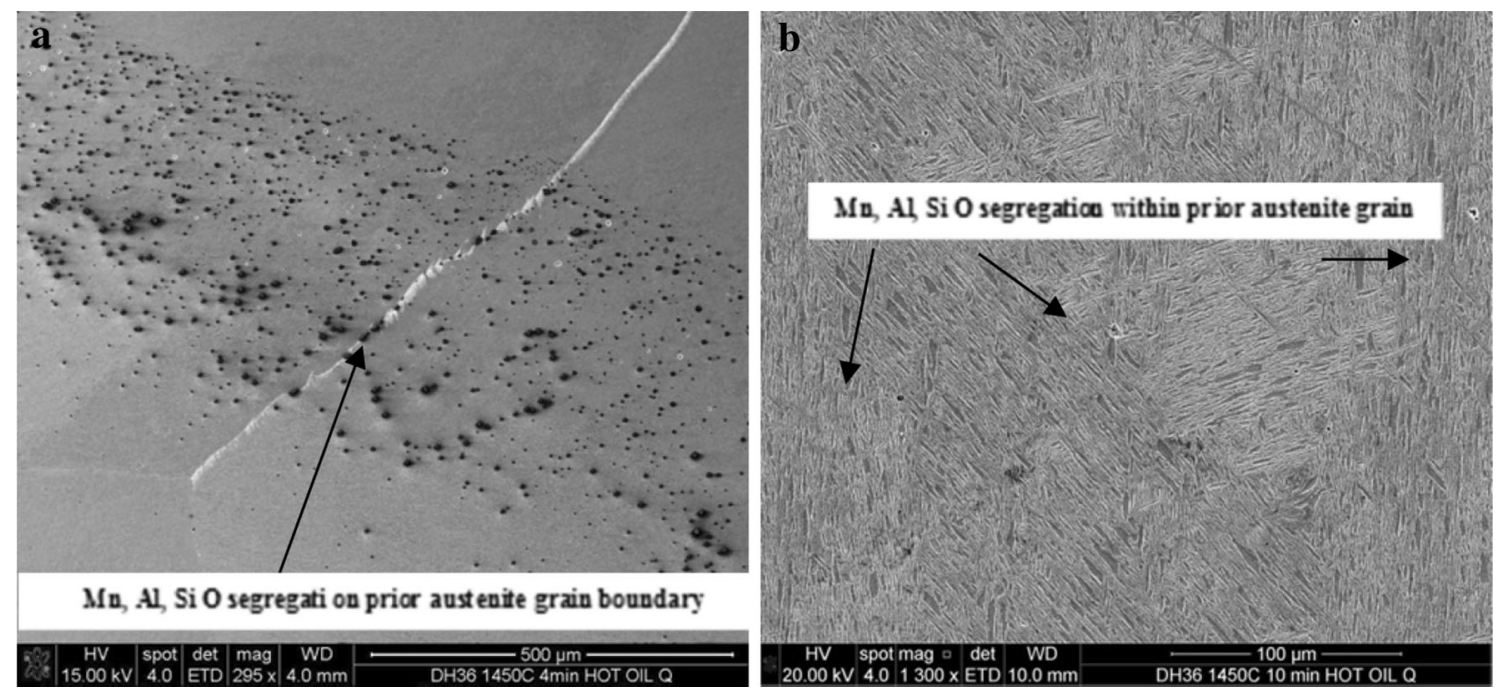

Fig. 5 Heat treatments at $1450{ }^{\circ} \mathrm{C}$ with cooling rate of $\left(30{ }^{\circ} \mathrm{C} / \mathrm{s}\right)$ hot oil quenching show $\mathrm{Mn}, \mathrm{Si}, \mathrm{O}$, and Al segregation in an acicular ferrite matrix. (a) Holding time $4 \mathrm{~min}$ and (b) holding time $10 \mathrm{~min}$
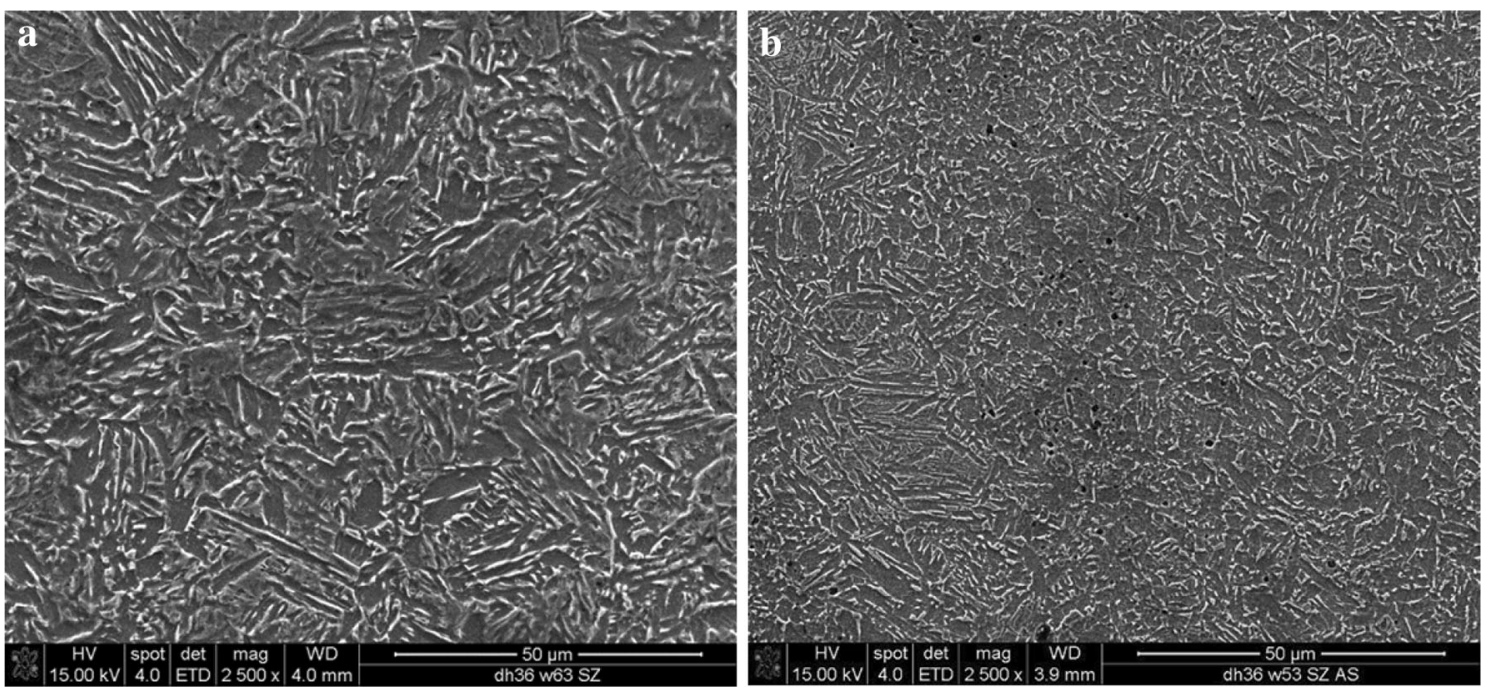

Fig. 6 SEM images of the stir zones of the low and high tool speed welds. (a) $W 1$ low tool speeds (100 mm/min, $200 \mathrm{RPM})$. (b) W2 high tool speeds $(400 \mathrm{~mm} / \mathrm{min}, 550 \mathrm{RPM})$
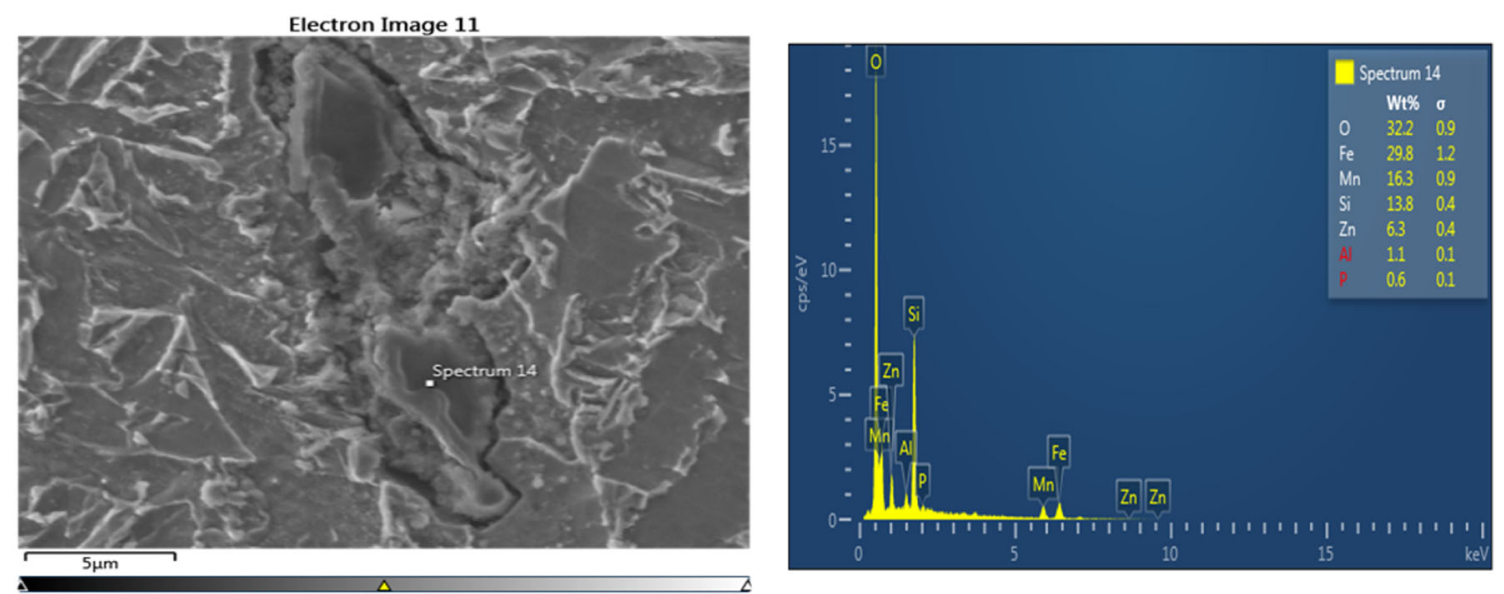

Fig. $7 \mathrm{Mn}, \mathrm{Si}, \mathrm{Al}, \mathrm{O}, \mathrm{Zn}$ segregation in FSW high tool speeds sample (W2) 
Fig. 8 (a-g) The steps of elemental segregation when heating at $1450{ }^{\circ} \mathrm{C}$ and changing the soaking time. (a) $\mathrm{MnS}-\mathrm{CaS}+\mathrm{Al}_{2} \mathrm{O}_{3}-\mathrm{CaO}$ (1-min soaking time).

(b) Forming one compound of $\mathrm{MnS}-\mathrm{CaS}+\mathrm{Al}_{2} \mathrm{O}_{3}-\mathrm{CaO}$ (3min soaking time). (c) $\mathrm{Si}, \mathrm{Nb}$, and $\mathrm{P}$ are incorporated in the compound (5-min soaking time). (d) Ca sulfide. (e) $\mathrm{Nb} \mathrm{P}$ sulfide. (f) $\mathrm{Mn}, \mathrm{Si}, \mathrm{Al}$, and $\mathrm{O}$ (10-min soaking time). (g) Mn, $\mathrm{Si}, \mathrm{Al}$, and $\mathrm{O}$ (10-min soaking time)

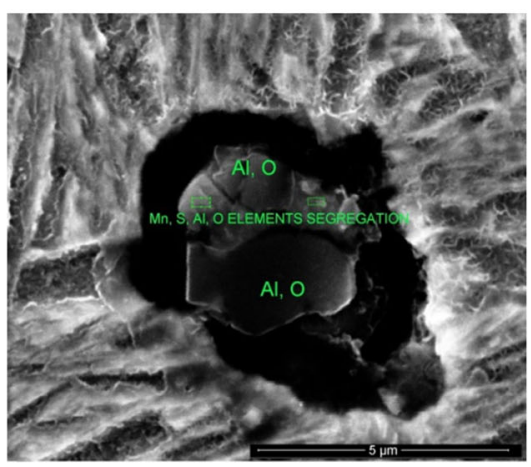

$\mathbf{a}$

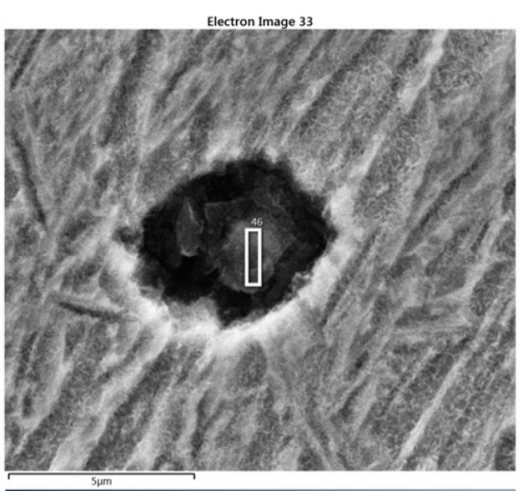

c

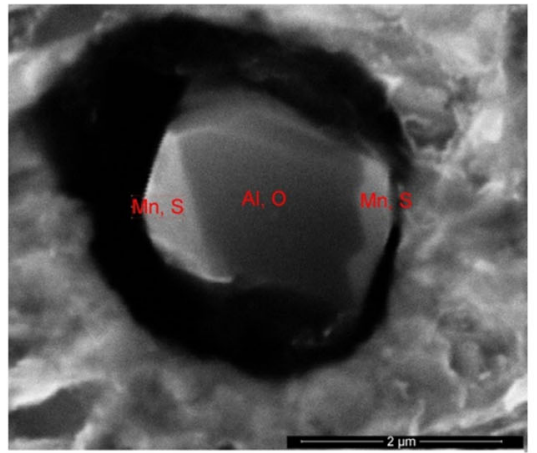

b

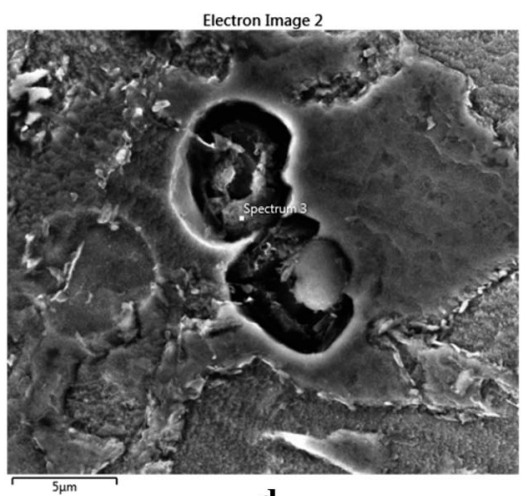

d

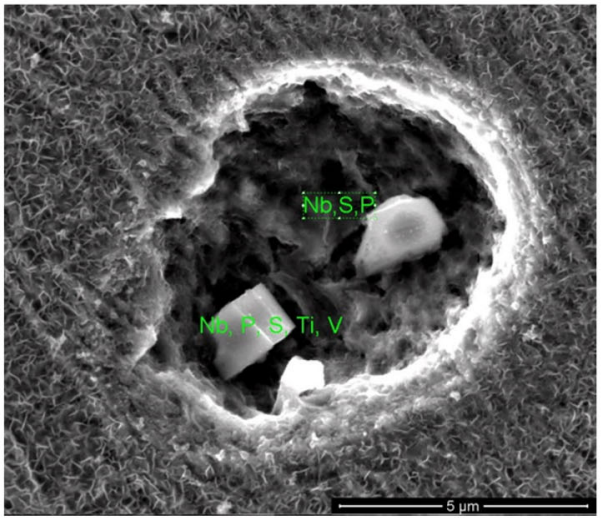

e

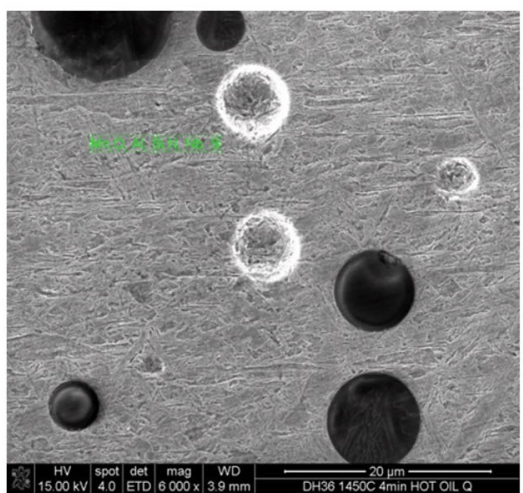

f

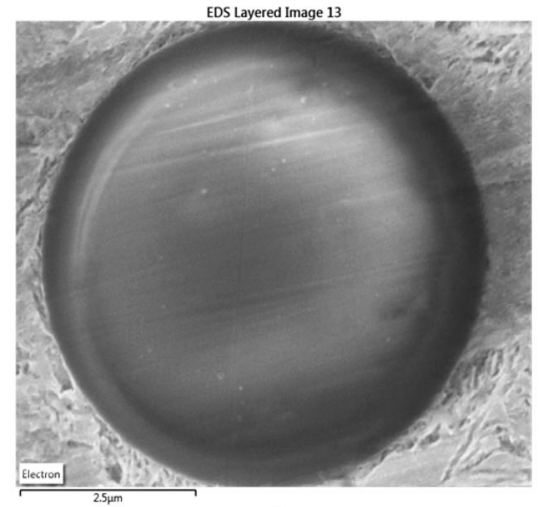

g 

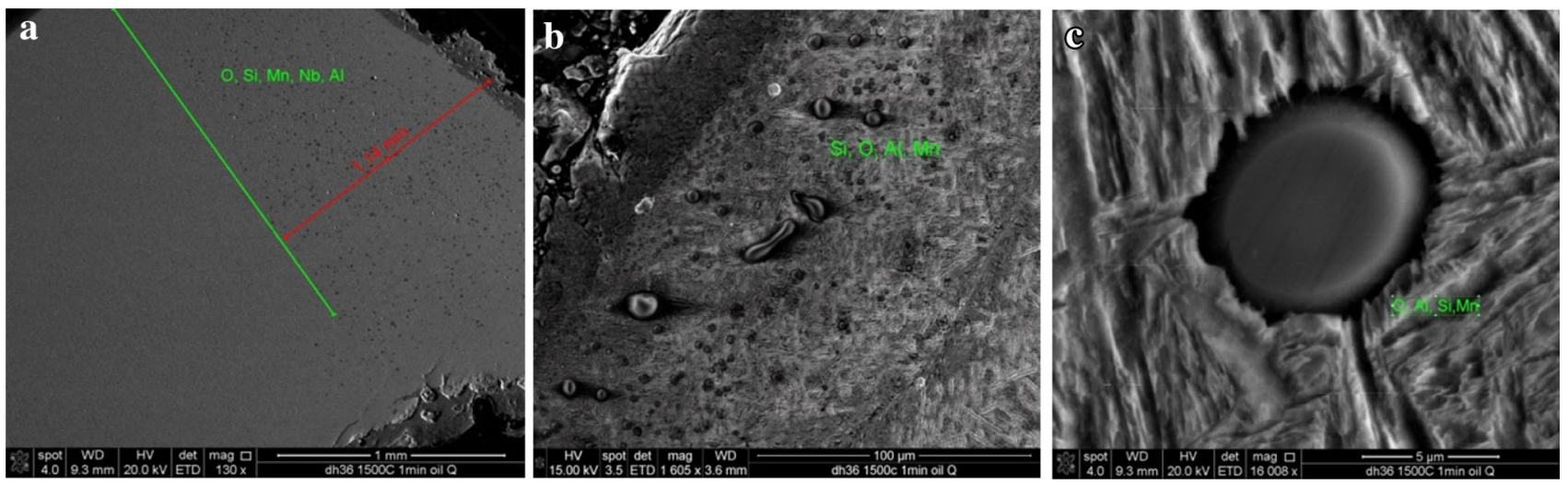

Fig. 9 Heat treatment with $1500{ }^{\circ} \mathrm{C}$ and cooling rate $30{ }^{\circ} \mathrm{C} / \mathrm{s}$, soaking time $1 \mathrm{~min}$. Segregation is forming with less soaking time when temperature approaches the melting point of base metal

distributed downward into the SZ under the effect of tool rotation and traverse speeds. This finding is in agreement with Arbegast et al. [18] who showed that material during FSW experiences upward flow into the shoulder and then downward flow into the extrusion zone around the tool. Thermocouple readings fixed at the bottom of the plates recorded peak temperatures of 850 and $910{ }^{\circ} \mathrm{C}$ for $W 1$ and $W 2$, respectively. These readings indicate that despite the high traverse speed of $W 2$, temperature is higher than the $W 1$, and this means that tool rotational speed is override the effect of traverse speed in terms of heat generation. An interpolation of thermocouples reading into the stirred zone can give an error because of the difference between the heat transfer mechanism between the stirred zones in which convection is dominant and the region away in which the heat transfer is by conduction [19].

In an effort to understand the formation of the complex oxides which have been identified in the FSW joints a series of heat treatments were carried at $1450{ }^{\circ} \mathrm{C}$ with holding times of between 1 and $10 \mathrm{~min}$. The temperature of $1450{ }^{\circ} \mathrm{C}$ was chosen because it showed the limit of elemental segregation and below this limit no segregation is likely to occur as mentioned in the heat treatments. The purpose of varying the soak time in the furnace was to establish knowledge of segregation progress with increasing time. Following heat treatment all the samples were quenched in oil at $22{ }^{\circ} \mathrm{C}$ which gives a cooling rate of approximately $30^{\circ} \mathrm{C} / \mathrm{s}$. Following oil quenching, all samples were sectioned, polished, and etched in preparation for microscopic examination of the microstructure. The results of the microstructural examination are presented in Fig. 8a-g. It can be seen in Fig. 8a (1-min soaking time) that segregation appears to be starting with the joining of $\mathrm{MnS}-\mathrm{CaS}$ with $\mathrm{CaO}-\mathrm{Al}_{2} \mathrm{O}_{3}$ to form a complex compound as shown in Fig. 8b which is an example of the chemical composition of the predominate second-phase particles in the matrix after 3-min soak time. The segregation appears to be advancing with time by more elements joining the complex compound such as $\mathrm{Si}, \mathrm{Nb}$, and $\mathrm{P}$ as shown in Fig. 8c (5-min soaking time). Then, a separation of sulfides from the main compound occurs including the formation of second-phase particles which are rich in calcium sulfide phosphorous and niobium sulfide as shown in Fig. 8d and e, respectively (7-min soaking time). The final compound with increasing holding time to $10 \mathrm{~min}$ elementally consists of $\mathrm{Mn}, \mathrm{Si}, \mathrm{Al}$, and $\mathrm{O}$ as shown in Fig. $8 \mathrm{f}$ and $\mathrm{g}$. This elemental segregation is expected to have a detrimental effect on the final welded joint mechanical properties [20]. This elemental segregation can be a source of microcracks and residual stresses and also the main matrix of steel is lost the benefit of uniform elemental distribution which were mainly added to steel during manufacturing in order to improve physical properties.

Figure 9 shows the elemental segregation of $\mathrm{Mn}, \mathrm{Si}, \mathrm{Al}$, and $\mathrm{O}$ along a distance of $1 \mathrm{~mm}$ from the edges of the heattreated sample at $1500{ }^{\circ} \mathrm{C}$ for holding time of $1 \mathrm{~min}$. The middle of the sample did not show elemental segregation, and this suggests that peak temperature away from the sample surface did not reach the maximum because of the limited holding time and also low thermal conductivity of steel.

It is worth highlighting that holding time for $1 \mathrm{~min}$ at $1500{ }^{\circ} \mathrm{C}$ was enough for $\mathrm{Mn}, \mathrm{Al}, \mathrm{Si}$, and $\mathrm{O}$ elemental segregation at the sample surface, and thus, it is expected that the time required for segregation is decreased with increasing temperature. In FSW, it is also expected that peak temperature at the advancing-trailing side is high enough for elemental segregation in a time of few seconds.

\section{Conclusion}

- SEM observations showed 6-mm-thick DH36 steel can be friction stir welded with a rotational speed limit up to $500 \mathrm{RPM}$ and traverse speed of $400 \mathrm{~mm} / \mathrm{min}$ without 
occurrence of any additional FSW-related elemental segregation.

- From heat treatment experiments of 6-mm cubic DH36 steel, the peak temperature at which elemental segregation starts was determined as $1450{ }^{\circ} \mathrm{C}$ with a cooling rate $30-50{ }^{\circ} \mathrm{C} / \mathrm{s}$.

- SEM observations showed that MnS-CaS appears to coalesce around existing $\mathrm{CaO}-\mathrm{Al}_{2} \mathrm{O}_{3}$ in $\mathrm{DH} 36$ microstructure. It appears that this evolution of the newly formed precipitates advanced with increasing soaking time by further joining other elements such as $\mathrm{Si}, \mathrm{Nb}$, and P. Finally, with extended time at $1450{ }^{\circ} \mathrm{C}$ the sulfur is separating from other sulfide compound such as phosphor sulfide, niobium phosphor sulfide, and calcium sulfide leaving the final segregated compound composed of $\mathrm{Mn}, \mathrm{Si}, \mathrm{Al}$, and oxygen.

- Increasing the peak temperature of heat treatment to $1500{ }^{\circ} \mathrm{C}$ reduced the holding time required to observe elemental segregation.

- The segregation of elements in the welded joints is expected to reduce mechanical properties which can be avoided by choosing the suitable tool rotational/traverse speed.

- Despite the fact that heat treatments did not include strain rate, they were useful to determine the limit of peak temperature at which elemental segregation of $\mathrm{Mn}, \mathrm{Si}, \mathrm{Al}$, and oxygen occurs.

\section{Future Work}

- To carry out mechanical tests including tensile and fatigue in order to study the effect of elemental segregation on the FSW joints strength.

- To carry out heat treatments at higher temperatures including the strain rate effect.

Acknowledgements The authors would like to thank TWI Company, especially Steve Cater, for providing data and samples and the ministry of higher education/Iraq for funding this study.

Open Access This article is distributed under the terms of the Creative Commons Attribution 4.0 International License (http://creative commons.org/licenses/by/4.0/), which permits unrestricted use, distribution, and reproduction in any medium, provided you give appropriate credit to the original author(s) and the source, provide a link to the Creative Commons license, and indicate if changes were made.

\section{References}

1. A. Toumpis, A. Gallawi, S. Cater, N. McPherson, Development of a process envelope for friction stir welding of DH36 steel-a step change. Mater. Des. 62, 64-75 (2014)
2. A.I. Toumpis, A. Gallawi, L. Arbaoui, N. Poletz, Thermo-mechanical deformation behavior of DH36 steel during friction stir welding by experimental validation and modelling. Sci. Technol. Weld. Join. 19(8), 653-663 (2014)

3. N.A. McPherson, A.M. Galloway, S.R. Cater, S.J. Hambling, Friction stir welding of thin DH36 steel plate. Sci. Technol. Weld. Join. 18(5), 441-450 (2013)

4. A.P. Reynolds, W. Tang, M. Posada, J. DeLoach, Friction stir welding of DH36 steel. Sci. Technol. Weld. Join. 8(6), 455-460 (2003)

5. Stevenson Ryan, Athanasios Toumpis, Alexander Galloway, Defect tolerance of friction stir welds in DH36 steel. Mater. Des. 87(15), 701-711 (2015)

6. D. Camilleri, D. Micallef, P. Mollicone, Thermal stresses and distortion developed in mild steel DH36 friction stir-welded plates: an experimental and numerical assessment. J. Therm. Stresses 38, 485-508 (2015)

7. Sebastian F. Medina, Quispe Alberto, Manuel Gomez, Model for strain-induced precipitation kinetics in microalloyed steels. Metall. Mater. Trans. A 45(3), 1524-1539 (2014)

8. S.F. Madina, J.E. Mancilla, Static recrystallization of austenite and strain induced precipitation kinetics in titanium microalloyed steels. Acta Metall. Mater. 42(12), 3945-3951 (1994)

9. Z.H. Zhu, S.T. Qiu, Effect of strain rate on $\mathrm{Nb}(\mathrm{C}, \mathrm{N})$ precipitation in micro alloy steel slab. Adv. Mater. Res. 535-537, 633-638 (2012)

10. Takashi Tanakaa, Takeshi Fujimatsub, Kazuya Hashimoto, Kazuhiko Hiraoka, Austenite grain stability of titanium-modified carburizing steel. Solid State Phenom. 118, 3-8 (2006)

11. P. Gong, E.J. Palmiere, W.M. Rainforth, Dissolution and precipitation behaviour in steels microalloyed with niobium during thermomechanical processing. Acta Mater. 97, 392-403 (2015)

12. D.M. Failla, Friction stir welding and microstructure simulation of HSLA-65 and austenitic stainless steels, in MSc. Thesis, (The Ohio State University, Ohio, 2009)

13. M. Lind, Mechanism and kinetics of transformation of alumina inclusions in steel by calcium treatment, in Doctoral Thesis, (Helsinki University of Technology, Espoo, 2006)

14. S. Yamini, Effect of titanium additions to low carbon, low manganese steel on sulphide precipitation, in $P h D$ Theses, (University of Wollongong, Wollongong, 2008)

15. A.B. Santillana, R. Boom, D. Eskin, H. Mizukami, M. Hanao, M. Amoto, High-temperature mechanical behaviour and fracture analysis of a low-carbon steel related to cracking, in Metallurgical and Materials Transactions A, vol 43A, (2012), pp. $5048-5057$

16. A. Smith, M. Al-Moussawi, A.E. Young, S. Cater, M. Faraji, Modelling of friction stir welding of 304 stainless steel. in European Simulation and Modelling Conference, (Univ. of Las Palmas, Las Palmas, (2016)

17. S.W. Baek, D.H. Choil, C.Y. Lee, B.W. Ahn, Y.M. Yeon, K. Song, S.B. Jung, Microstructure and mechanical properties of friction stir spot welded galvanized steel. Mater. Trans. 51(5), 1044-1050 (2010)

18. W.J. Arbegast, in Z. Jin, A. Beaudoin, T.A. Bieler, B. Radhakrishnan (Eds.), Hot Deformation of Aluminum Alloys III, TMS, Warrendale, 2003, p. 313

19. D. Fairchild, A. Kumar, S. Ford, N. Nissley, Research concerning the friction stir welding of linepipe steels, in Proceedings of the 8 th International Conference on Trends in welding research, 2009, pp. 371-380

20. M. Al-moussawi, A. Smith, A. Young, S. Cater, M. Faraji, An advanced numerical model of friction stir welding of DH36 steel, in 11th International Symposium FSW, (TWI Granta Park Cambridge, Cambridge, 2016) 